\title{
Dengue in Brazil and Colombia: a study of knowledge, attitudes, and practices
}

\author{
Solange Laurentino dos Santos ${ }^{[1]}$, Gabriel Parra-Henao ${ }^{[2]}$, Mírcia Betânia Costa e Silva ${ }^{[1]}$ \\ and Lia Giraldo da Silva Augusto ${ }^{[3]}$
}

[1]. Departamento de Medicina Social, Universidade Federal de Pernambuco, Recife, PE. [2]. Grupo de Epidemiologia y Bioestadistica, Universidad CES, Medellín, Colômbia. [3]. Faculdade de Ciências Médicas, Universidade de Pernambuco, Recife, PE.

\begin{abstract}
Introduction: This study was conducted in Brazil and Colombia,where dengue is endemic and vector control programs use chemical insecticides. Methods: We identified knowledge, attitudes, and practices about dengue and determined the infestation levels of Aedes aegypti in one Brazilian and four Colombian communities. Results: The surveys show knowledge of the vector, but little knowledge about diagnosis, prognosis, and treatment. Vector infestation indices show Brazil to have good relative control, while Colombia presents a high transmission risk. Conclusions: Given the multidimensionality of dengue control, vertical control strategies are inadequate because they deny contextualized methods, alternative solutions, and local empowerment.
\end{abstract}

Keywords: Dengue. Knowledge. Practices. Brazil. Colombia.

Four types of dengue virus (DENV) circulate in Latin America, with six countries including Brazil and Colombia having DENV 1, 2, 3, and 4. Up to epidemiological week 36 of 2012, Brazil had the highest incidence with 248/100,000, while Colombia represented an incidence of $157 / 100,000$. During this period, Braziland Colombia had $130(36 \%)$ and $36(15 \%)$ deaths, respectively, out of the Latin American total mortality of $376^{1}$.

Brazil's population is $190,732,694$, distributed in 5,565 municipalities ${ }^{2}$. Dengue is endemic with recurrent epidemic outbreaks. Ten out of 27 states had $81.6 \%(233,488)$ of cases reported in the first trimester of $2012^{3}$. In Brazil, the Program for Eradication of Aedes aegypti began in 1950, but in 1985 the focus was modified to control. In 1996, Brazil regressed to a model of eradication, and the National Plan for Eradication of Ae. Aegypti ${ }^{4}$ was implanted in 3,701 municipalities. In 2002, DENV 3 was introduced, leading to an emergency National Plan for Dengue Control [Programa Nacional de Controle da Dengue (PNCD) $]^{5}$, a permanent program in all municipalities. In 2012, Brazil purchased 2.5 million $k g$ of larvicide and 350 million L of adulticide ${ }^{3}$.

In Colombia, a country with a population of $46,722,777$ distributed in 1,103 municipalities, the disease has become endemic with frequent outbreaks 6 . Six of 32 municipalities showed $55.36 \%(20,394)$ of the cases of the first nine months

\footnotetext{
Address to: Dra. Solange Laurentino dos Santos. Depto. de Medicina Social/ UFPE. Av. da Engenharia s/n, Cidade Universitária, 50740-600 Recife, PE, Brasil. Phone: 5581 2126-8550; Fax: 5581 2126-8558

e-mail: solange.lsantos@ufpe.br

Received 29 April 2014

Accepted 21 August 2014
}

of 2012. Currently all four serotypes circulate throughout the country ${ }^{7}$. A campaign to eradicate Ae. aegypti began in the early 1950 s, and the country was said to be free of infestation by 1952. Columbia's Ministry of Health $(\mathrm{MoH})$ operates under the National Plan of Basic Attention Beginning in 2006, the $\mathrm{MoH}$ adopted a national integrated control strategy with intersectorial, multidisciplinary, and community participation and a vector control program based mainly on the use of insecticides.

We compared levels of consciousness and conduct in one Brazilian and four Colombian communities. These field studies were realized in two stages: I) An entomological survey using the House Index and Breteau Index. In Brazil this survey was done bimonthly over one year (2008); in Colombia, this survey was conducted at three times, time zero (TO), time one (T1), and time two last intervention (T2), from 2008-2010; II) A survey of knowledge, attitudes, and practices of a sample of residents, using a standardized household survey about knowledge of the disease, activities of prevention, and control of vectors, water supply, sanitation, and home reservoirs in Latin America.

The Brazilian study site was the neighborhood Santa Rosa in the municipality of Cabo de Santo Agostinho, State of Pernambuco, which is a tourist and port complex of 448 square $\mathrm{km}$ with a population of $152,997,87.9 \%$ of whom are urbanized, and with relative socioeconomic homogeneity. Its 813 domiciles manifest a $50 \%$ dengue incidence with a $\pm 5 \%$ confidence interval based on a 263 -domicile sample ${ }^{2}$. The $\mathrm{N}=263 / 813$ households were calculated with an estimated $50 \%$ incidence at a $\pm 5 \%$ error interval. The study covered 852 persons, with a mean of four persons per domicile, and the study period was 2007-2009. In Colombia, four neighborhoods in the municipalities of Apartado (La Alborada and La Arboleda) and Carepa (Obrera and Cadena) in Antioquia State were chosen 
for their high dengue incidence. Situated on the Caribbean coast, the municipality of Apartado has an area of 600 square $\mathrm{km}$, of which $5.65 \mathrm{~km}^{2}$ are urban with 114,840 inhabitants ${ }^{6}$. The municipality of Carepa is 380 square $\mathrm{km}$, of which 3.2 square $\mathrm{km}$ are urban. Neighborhoods were chosen for their $50 \%$ dengue incidence with $\pm 5 \%$ error. The $\mathrm{N}=200 / 422$ households were calculated with a $50 \%$ incidence at a $\pm 5 \%$ error interval. The four neighborhoods were studied from 2008-2010.

The results show the vector infestation indices to have good relative control in the municipality in Brazil, while the municipalities in Colombia present a high transmission risk. In Santa Rosa in six cycles of 2008, the House Index ranged between 1.28 and $0.47 \%$ March and December, while in Colombia the average index average varied from 55.2 to 22.5 to $37.6 \%$ infestation in the three time samples, showing that infestation was increasing. See Figure 1 for the House Index and Breteau Index in Brazil and Figure $\mathbf{2}$ for the House Index in Colombia.

Our surveys show knowledge of the vector and its anthropophilic habits but little knowledge about diagnosis, prognosis, and treatment or home care of infected persons. Our results regarding knowledge, attitudes, and practice in the two countries is presented in Table 1. These results are to be expected as the mass media campaigns and community agents focus on reservoir management and spraying. In both countries, people realize that dengue is a serious condition that can kill, but do not know about mechanical prevention beyond vector control (window screens, bed nets, etc.) or the signs and symptoms of the illness.

During the investigation, it was observed in Brazil that Environmental Health Agents initiated local control programs, including the application of temephos (Abate) in home water reservoirs for larval control, despite studies showing possible resistance since 1991 and the indication for integration of biological and chemical insecticides to control mosquito larvae ${ }^{8}$. It was also observed that the Brazilian community is better organized than its Colombian counterparts, with paved streets and public sanitation. In the discussion of the results, we consider that the Brazilian control campaigns use intense and expensive $(\mathrm{R} \$ 1 \text { billion per year })^{9}$ mass media coverage and social mobilization, while in Colombia less social mobilization and media coverage is observed.

Despite some methodological differences in the study applied in the two countries, the comparative contextual analyses show how different levels of public sanitation and urbanization influence dengue vector infestation, income, and public health. In Brazil, despite $\mathrm{R} \$ 1$ billion spent in $2002^{9}$,

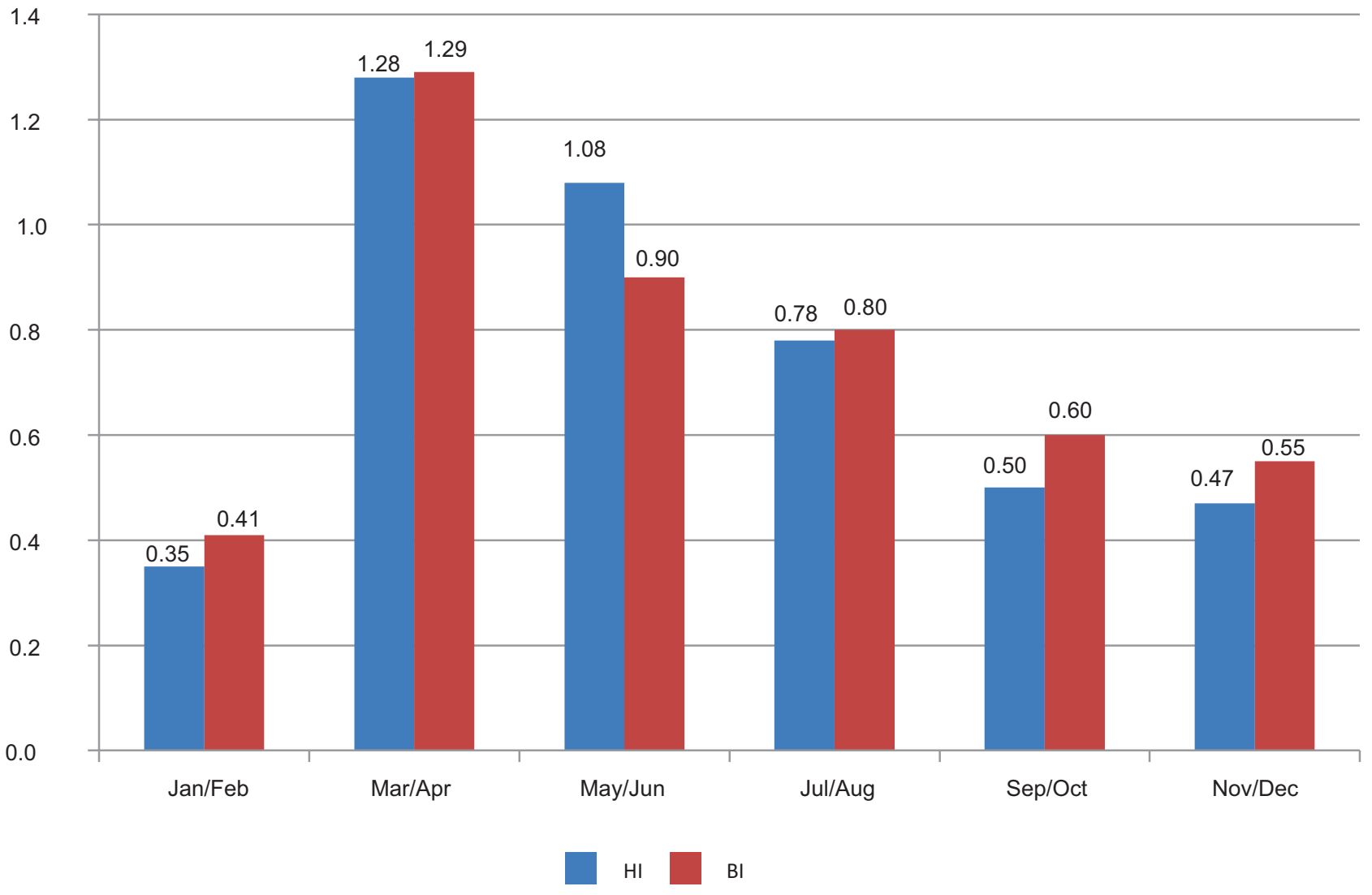

FIGURE 1 - House Index and Breteau Index by bimonthly cycle in Santa Rosa Brazil, 2008. Source: Field study in Santa Rosa, Cabo de Santo Agostinho, State of Pernambuco, 2007-2009. HI: House Index; BI: Breteau Index. 


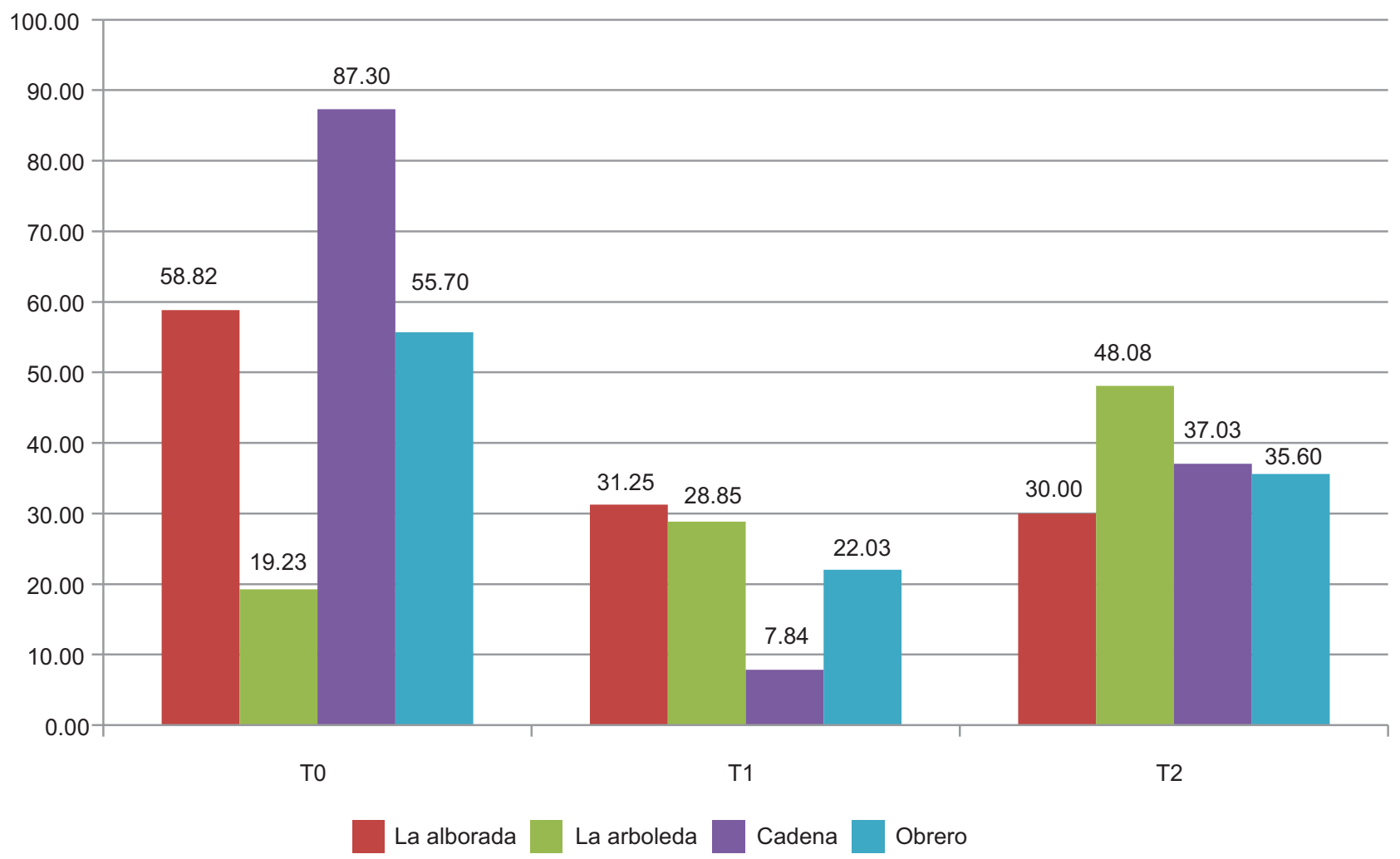

FIGURE 2 - House Index scores in the neighborhoods of La Alborada, La Arboleda, Cadena, and Obrero, Colombia, 2008-2010. Source: Field study in Colombia, 2008-2010. T0: time zero; T1: time one; T2: time two.

$85 \%$ of which was dedicated to vector control, a 2005 PNCD study showed the low effectiveness of this expensive strategy ${ }^{10}$.

Colombia's politically verticalized and chemical-dependent model, like Brazil's, needs to incorporate long-term strategies to abate socio-environmental vulnerability. Unsatisfactory knowledge, attitudes, and practice at the population level are related to heightened risk of transmission and can only be overcome with education and social mobilization adapted to local cultural and linguistic contexts, which are richly diverse in all countries in Latin America. Another study in Colombia showed that after an education intervention in schoolchildren, the knowledge about vector control measures increased from $65.2 \%$ to $82.6 \%{ }^{11}$. Dengue has a low lethality of about $2.5 \%$ with proper clinical attention ${ }^{12}$, but in poor communities it is crucial that population education about environmental signs of risk, symptoms, and treatment with good clinical practice be applied to reduce morbidity and mortality.

In 147 Brazilian municipalities with verified resistance to temephos, the population of Ae. aegypti showed mortality under $80 \%$; alternatively, the ratio of resistance to a $95 \%$ lethal dose
(RR95) was greater than $3.0^{13}$. Brazil has changed to the use of diflubenzuron, and Colombia (at least in the study communities) has adopted Bacillus thuringiensis israelensis. In Colombia, there are few reports of resistance in Ae. aegypti populations, and the control methods seem to be working ${ }^{14}$.

Fieldwork that is participatory, multidisciplinary, and local, like that developed in this and other related articles ${ }^{15}$ is necessary to understand and correct attitudes and interactions between persons and health care institutions; to incentivize popular mobilization and participation in micro-environmental management, prevention, and patient care; and to lower the spread of dengue serotypes and fatalities.

The differences between Brazil and Colombia in the index of infestation are marked. In Brazil, vectorial infestation was controlled at levels below two percent, with a declining tendency during the study years, even considering the seasonality of the vector. In the Colombian cities, there was a dramatically high infestation in the cycles monitored during the study, as in the Cadena neighborhood with infestation varying from 87.3 to 7.84 to $37.03 \%$ in the three annual cycles. 
TABLE 1 - Survey results of knowledge, attitudes, and practice regarding dengue and its vector, individual control measures, insecticide, and water management in Brazil and Colombia.

\begin{tabular}{lcc}
\hline Survey country & Brazil $(\mathrm{n}=263)$ & Colombia $(\mathrm{n}=200)$ \\
\cline { 2 - 3 } & Cabo Santo Agostinho & Carepa \\
Santa Rosa & La Alborada e La Arboleda & Obrero e Cadena \\
\hline
\end{tabular}

\section{Knowledge}

How dengue is transmitted? (n; \%) report by mosquitoes $(259 ; 98.5)$ report by mosquitoes $(158 ; 79.0)$

Do you know the mosquito

types that transmit dengue? (n; \%)

How serious is dengue? (n; \%)

How can dengue be prevented? (n; \%) know the mosquito types $(233 ; 88.6)$

confuse Aedes Aegypti with Culex quinquefasciatus $(79 ; 30.0)$

report that dengue kills $(255 ; 96.9)$

report that dengue can be prevented with vector control $(236 ; 89.7)$ report that dengue can be prevented through patient care $(3 ; 1.1)$

What collective precautions should the patient take with dengue? (n; \%)

Individual means of prevention (n; \%)

report water management $(82 ; 31.2)$

report better trash collection $(50 ; 19.0)$ do not know $(45 ; 17.1)$

report individual action $(236 ; 89.7)$

report domestic water protection $(82 ; 31.2)$ know the mosquito types $(176 ; 88.0)$

confuse with Tipulidae gender Tipula $(105 ; 52.5)$

report that dengue kills $(192 ; 96.0)$

report no response $(100 ; 50.0)$

report that dengue can be prevented by medical treatment $(59 ; 29.5)$

do not know $(100 ; 50.0)$

report mosquito control $(30 ; 15.0)$

report disposal of washing water reservoirs $(34 ; 17.0)$

report reservoir protection (100; 50.0)

report using larvicides in water and domestic reservoirs $(100 ; 50.0)$

On insecticide use (n; \%) report it can be bad for health $(132 ; 50.2)$

report the community agent puts

chemical larvicide in the water $(228 ; 86.7)$

report no use of insecticide to kill

adult insects $(165 ; 62.7)$

report that insecticides are chemical products that can be affect health $(116 ; 44.1)$

do not know the difference between

biological and chemical control $(216 ; 82.1)$ report chemical prevention $(20 ; 10.0)$

report no health problems $(200 ; 100.0)$

\section{Attitudes and practices}

Preventing the illness (n; \%)

Vector control (n; \%) report taking care of water reservoirs $(108 ; 41.1)$

report insufficient practical action to control the vector or stop its reproduction $(126 ; 47.9)$ report putting garbage in a closed container $(213 ; 81.0))$ report closing reservoirs $(198 ; 75.3)$ report using insecticide in water $(231 ; 87.8)$

report using bed nets $(49 ; 18.6)$ report using screens on doors and windows $(16 ; 6.1)$ report calling the doctor $(4 ; 2.0)$ report controlling the mosquitoes $(30 ; 15.0)$

report insufficient practical action to control the vector or stop its reproduction $(104 ; 52.0)$

report periodically washing water containers $(96 ; 48.0)$ report cleaning water reservoirs, tanks, and containers $(34 ; 17.0)$

report using bed nets $(12 ; 6.0)$

report using screens on doors and windows $(16 ; 8.0)$ 


\section{ACKNOWLEDGMENTS}

The authors would like to thank the International Development and Research Centre, for training, the municipalities of Cabo de Santo Agostinho in Brazil and Apartado and Carepa in Colombia and, the Centro de Pesquisas Aggeu Magalhães/Fundação Oswaldo Cruz (CPqAM/FIOCRUZ).

\section{CONFLICT OF INTEREST}

The authors declare that there is no conflict of interest.

\section{FINANCIAL SUPPORT}

This study was funded by the Fundação de Amparo à Ciência $e$ Tecnologia of the State of Pernambuco (FACEPE)/Conselho Nacional de Desenvolvimento Científico e Tecnológico/ Ministério da Saúde (CNPq/MS) in Brazil; the Colciências Colombia e Universidad CES in Colombia; and the International Development and Research Centre for training the authors.

\section{REFERENCES}

1. Pan American Health Organization (PAHO). World Health Organization (WHO). Number of Report Cases of Dengue and Figures for 2012. Epidemiological week 36. [cited 2012 Oct 08]. Available at: http://new.paho.org/hq/index.php?option=com_conten t\&view $=$ article\&id $=4494 \&$ Itemid $=2481$.

2. Instituto Brasileiro de Geografia e Estatística (IBGE). Population Censuses 2010. [Internet]. [Cited 2012 May 24] Available at: http:// www.ibge.gov.br/english/estatistica/populacao/censo2010/default. shtm.

3. Ministério da Saúde. Secretaria de Vigilância em Saúde. Brasil reduz em 84\% o número de mortes por dengue em 2012. Brasília, DF; 2012. [Internet]. [Cited 2012 May 18]. Available at: http://portal.saude.gov.br/
portal/aplicacoes/noticias/default.cfm?pg=dspDetalheNoticia\&id area $=1498 \&$ CO_NOTICIA $=13943$.

4. Ministério da Saúde. Fundação Nacional de Saúde (FUNASA). Plano Diretor de Erradicação do Aedes aegypti no Brasil: versão atualizada em: 01 de mar. Brasília, DF: FUNASA; 1996.

5. Ministério da Saúde. Fundação Nacional de Saúde (FUNASA). Programa Nacional de Controle da Dengue: instituído em 24 de julho de 2002. Brasília, DF: FUNASA; 2002.

6. Departamento administrativo nacional de estadística (DANE). Censo General 2005. [Internet]. [Cited 2012 May 24]. Available at: http://www.dane.gov.co/index.php?option=com_content\&view $=$ art icle\&id=307\&Itemid=124.

7. Ministerio de Protección Social de Colombia. Protocolos y guias para la gestion de la vigilancia en salud publica, atencion clinica integral y control vectorial de las enfermedades transmitidas por vectores. Bogota: Ministerio de Proteccion Social de Colombia; 2010.

8. Andrade CFS, Modolo M. Susceptibility of Aedes aegypti larvae to temephos and Bacillus thuringiensis var israelensis in integrated control. Rev Saude Publica 1991; 25:184-187.

9. Braga IA, Valle D. Aedes aegypti: histórico do controle no Brasil. Epidemiol Serv Saude 2007; 16:113-118.

10. Santos SL, Augusto LGS. Dengue: uma avaliação das ações do programa de controle. Cad Saude Coletiva 2005; 13: 263-280.

11. Restrepo BN, Pineda JM, Parra-Henao G. Application and evaluation of educational materials for dengue prevention in an educative institution of Medellin, Colombia. Rev CES Medicina 2011; 25:31-41.

12. Kouri G. El dengue un problema cresciente en las Americas. Rev Panam Salud Publica 2006; 19:143-145.

13. Ministério da Saúde. Resumo Executivo do II Seminário Internacional para Avaliação de Ações de Controle Químico de Aedes aegypti no Brasil [Internet]. 2012; [Cited 2012 May 18]. Available at: http://portal.saude.gov.br/portal/saude/profissional/ visualizar_texto.cfm?idtxt $=40134$.

14. Santacoloma L, Chaves B, Brochero E. Estado de susceptibilidade de poblaciones naturales del vector del dengue a insecticidas en trece localidades de Colombia. Rev Biomédica 2012; 32:333-343.

15. Bonet M, Spiegel JM, Ibarra AM, Kouri G, Pintre A, Yassi A. An integrated ecosystem approach for sustainable prevention and control of dengue in Central Havana. Int J Occup Environ Health 2007; 13:188-194. 